\title{
Formation and Characterization of Irreversible Sediment of Ginseng Extract
}

\author{
Di Qu ${ }^{1,2}$, Mei Hua ${ }^{2}$, Jian-Bo Chen ${ }^{2}$, Shan-Shan $\mathrm{Li}^{2}$, Lian-Kui Wen ${ }^{1, *}$ and Yin-Shi Sun ${ }^{2, *}$ (C) \\ 1 Institute of Food Science and Engineering, Jilin Agricultural University, Changchun 130118, China; \\ qudi@caas.cn \\ 2 Institute of Special Animal and Plant Sciences, Chinese Academy of Agricultural Sciences, \\ Changchun 130112, China; huamei@caas.cn (M.H.); chenjianbo00882@126.com (J.-B.C.); \\ lishanshan@caas.cn (S.-S.L.) \\ * Correspondence: wenliankui@163.com (L.-K.W.); sunyinshi2015@163.com (Y.-S.S.)
}

Citation: Qu, D.; Hua, M.; Chen, J.-B.; Li, S.-S.; Wen, L.-K.; Sun, Y.-S. Formation and Characterization of Irreversible Sediment of Ginseng Extract. Foods 2021, 10, 2714. https:// doi.org/10.3390/foods10112714

Academic Editors: Laura

G. Gómez-Mascaraque and Antonio Martínez-Abad

Received: 13 October 2021

Accepted: 29 October 2021

Published: 5 November 2021

Publisher's Note: MDPI stays neutral with regard to jurisdictional claims in published maps and institutional affiliations.

Copyright: (c) 2021 by the authors. Licensee MDPI, Basel, Switzerland. This article is an open access article distributed under the terms and conditions of the Creative Commons Attribution (CC BY) license (https:/ / creativecommons.org/licenses/by/ $4.0 /)$.

\begin{abstract}
Sediment is a key issue in the beverage industry. This study confirmed that reversible and irreversible sediments were formed during low-temperature storage of ginseng extract. The first 30 days of storage are the critical period for sediment formation. As the time of storage extends, the chemical composition changes. The composition interaction model verified that the cross-linking of protein-pectin, protein-oxalic acid and $\mathrm{Ca}^{2+}$-pectin was the main cause of the turbidity of ginseng extract. Based on the characterization of irreversible sediment (IRS), there are typical structures of proteins, polysaccharides and calcium oxalate dihydrate (COD) crystals. Glucose, galacturonic acid, aspartate, glutamic acid, leucine, $\mathrm{Ca}, \mathrm{K}, \mathrm{Al}, \mathrm{Mg}, \mathrm{Na}$ and $\mathrm{Fe}$ are the main monomer components. Effective regulation of these ingredients will greatly help the quality of ginseng beverages.
\end{abstract}

Keywords: ginseng; botanical beverages; chemicals; sediment; structural characterization

\section{Introduction}

Botanical functional beverages have been developing rapidly in recent years because of their unique and natural health advantages. Ginseng (Panax ginseng C.A.Mey) contains saponins, polysaccharides, amino acids, minerals and other nutrients [1,2]. It has antifatigue, antiaging, antitumor and other effects [3-5]. Ginseng is widely used in health food in China, South Korea, Japan and other Asian countries as a medicine-food homologous material. However, ginseng beverages generate sediment during storage, which not only affects the appearance quality of the product but also reduces the unique aroma and flavor of ginseng beverages and causes the loss of functional ingredients. At present, physical methods such as filtration are mainly used to remove this type of sediment, but these methods are not effective enough [6,7]. Therefore, elucidating the formation mechanism of ginseng beverage sediment can provide basic support for the precise regulation of sediment and help improve the quality of ginseng beverages.

Beverage sediment is a key issue of common concern by scholars in the industry, and the formation of beverage sediment has an important relationship with the interaction of chemical components in plants [8]. There were significant differences in chemical composition of different parts and ages of ginseng. Carbohydrates are the most abundant chemical components in ginseng, followed by protein [9]. Part of the sediment can be reheated and reconstituted into reversible sediment (RS), and the irreversible part is called irreversible sediment (IRS), which is similar to the sediment in green tea [10]. The common phenomenon of turbidity in beverages is a result of polyphenol-protein interactions, which bind noncovalently and are reversible in the early stage of sediment formation [11]. The binding between polysaccharides and proteins is another reason for sediment formation. Sediment formation is a spontaneous process promoted by electrostatic interactions, hydrogen bonding and van der Waals forces [12]. The polysaccharide-protein interaction is 
reversible. When the $\mathrm{pH}$ value is lower than the isoelectric point of the protein, the protein is positively charged and can form complex coacid salts. When the $\mathrm{pH}$ value is higher than the isoelectric point of the protein, the anionic glycan forms weak electrostatic interactions with the positively charged part of the protein, resulting in the formation of soluble complexes $[13,14]$. Minerals and organic acids in plants can combine to form insoluble mineral salts [15-17]. The irreversible sediment of green tea is mainly the combination of $\mathrm{Ca}^{2+}$ and oxalic acid [18]. The crystalline component in the sediment of barberry juice forms from potassium salt [17]. The tartrate in grape juice will be deposited as the temperature decreases during crystallization [19]. In addition, sediment will be deposited with the extension of storage time, and the phenolic substances in mulberry juice will gradually precipitate [20]. Caffeine and proteins in the reversible sediment of green tea are significantly increased, and most of the minerals participate in the formation of a precipitate [21].

The complexation of chemical components in beverages can significantly affect the functional properties of food, such as solubility, surface activity, conformation stability, gel formation ability, emulsification ability, etc. At present, there are few studies on the sediment in ginseng extracts. This article studies ginseng extract stored at low temperature for 0-50 days, analyzes the chemical composition of reversible and irreversible sediments, establishes component interaction model, and reveals the sediment formation mechanism through the structural characterization of IRS. It also provides a theoretical basis for the inhibition of ginseng beverage sediment formation and the retention of functional components.

\section{Material and Methods}

\subsection{Graphical Scheme of the Approach of the Study}

The technology roadmap for the study is as follows:

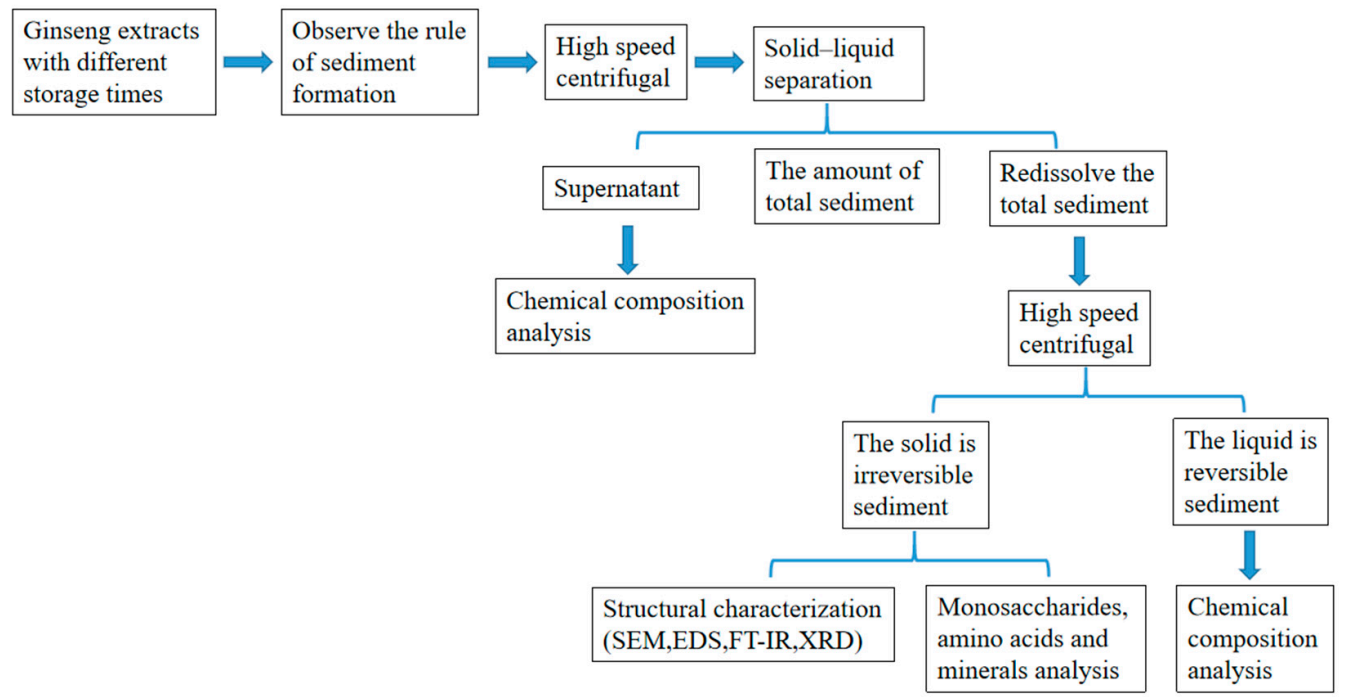

\subsection{Preparation of a Ginseng Extract}

Panax ginseng (five years old) was produced in Fusong County, Jilin Province. After crushing and sieving, 20- to 60-mesh particles and purified water were extracted at $80{ }^{\circ} \mathrm{C}$ for $60 \mathrm{~min}$ at a mass ratio of 1:10. The purified ginseng extract was filtered with a doublelayer 300 filter cloth and centrifuged at $5000 \mathrm{rpm}$ for $15 \mathrm{~min}$. The purified ginseng extract was separated into $50 \mathrm{~mL}$ centrifuge tubes and pasteurized $\left(90^{\circ} \mathrm{C}, 5 \mathrm{~min}\right)$.

\subsection{Observation of Precipitate Formation}

The prepared ginseng extract was stored at $4{ }^{\circ} \mathrm{C}$ for 50 days. After centrifugation $(10,000 \mathrm{rpm}, 15 \mathrm{~min})$, the sediments were described in terms of sediment amount, color 
and morphology and were evaluated every 10 days. The evaluation team was composed of 9 teachers majoring in food science.

\subsection{Preparation of $R S$ and IRS}

The stored ginseng extract was centrifuged at 10,000 rpm for $15 \mathrm{~min}$, and the supernatant was removed. The total sediment (TS) was diluted to $50 \mathrm{~mL}$ with purified water, heated at $70{ }^{\circ} \mathrm{C}$ for $20 \mathrm{~min}$, vibrated and then centrifuged (10,000 rpm, $15 \mathrm{~min}$ ) to separate the precipitates. The liquid part was RS, and the bottom sediment was IRS.

\subsection{Determination of the Amount of Sediments}

The separated total sediment and IRS were dried at $80^{\circ} \mathrm{C}$ for $48 \mathrm{~h}$ and weighed. The specific procedure was performed according to Nagalakshmi et al. (1984) [22].

\subsection{Analysis of Chemical Composition}

\subsubsection{Analysis of Total Sugar, Protein and Total Free Amino Acids}

The total sugar content was determined by the phenol-sulfuric acid method. Glucose was used as the reference substance. Then, $0.5 \mathrm{~mL}$ of $5 \%$ phenol and $2.5 \mathrm{~mL}$ of sulfuric acid were added to a $1 \mathrm{~mL}$ sample and mixed quickly; the sample was kept at $40{ }^{\circ} \mathrm{C}$ for $30 \mathrm{~min}$ and then rapidly cooled to room temperature [23]. The optical density (OD) was measured at $490 \mathrm{~nm}$ using an EPOCH microplate reader (Bio Tek Instruments, Inc., Highland Park, Winooski, Vermont, USA). The calculation formula is as follows: total sugar content $\left(\mathrm{mg} \cdot \mathrm{mL}^{-1}\right)=10.979 \times \mathrm{OD}_{490}+0.0059, R^{2}=0.9994$.

The protein content was determined by a BCA Protein Quantitative Kit (Sangon Biotech, Shanghai, China).

The content of total free amino acids was determined by ninhydrin colorimetry. Glutamic acid was used as the reference substance. Then, $0.5 \mathrm{~mL}$ of buffer solution at $\mathrm{pH}=6.81$ and $0.5 \mathrm{~mL}$ of $20 \mathrm{~g} / \mathrm{L}$ ninhydrin solution were added to $1 \mathrm{~mL}$ of sample and heated in boiling water for $15 \mathrm{~min}$. After cooling, the volume was fixed to $25 \mathrm{~mL}$, and the OD was determined at $570 \mathrm{~nm}$ [24] according to the following formula: total free amino acid content $\left(\mathrm{mg} \cdot \mathrm{ml}^{-1}\right)=2.012 \times \mathrm{OD}_{570}-0.2058, R^{2}=0.9997$.

\subsubsection{Analysis of Total Saponins}

The total saponins were determined by the vanillin-sulfuric acid method. Ginsenoside Re was used as the reference substance. A $40 \mu \mathrm{L}$ sample was evaporated, and $0.2 \mathrm{~mL}$ of $5 \%$ vanillin and $1 \mathrm{~mL}$ of $72 \%$ sulfuric acid were added. The reaction was carried out at $60{ }^{\circ} \mathrm{C}$ for $15 \mathrm{~min}$. After cooling, $5 \mathrm{~mL}$ of glacial acetic acid was added and mixed evenly. The optical density (OD) was determined at $560 \mathrm{~nm}$. The formula for the calculation was as follows: total saponin content $\left(\mathrm{mg} \cdot \mathrm{ml}^{-1}\right)=2.0055 \times \mathrm{OD}_{560}-0.001, R^{2}=0.9993$.

\subsubsection{Analysis of Ginsenosides}

The 8 ginsenosides to be tested were dissolved in methanol. The standard and tested samples were filtered through a $0.22 \mu \mathrm{m}$ (gold) filter and then analyzed by ultrahighperformance liquid chromatography (UPLC). The analysis was carried out on a Waters HSS T3 liquid chromatography system, which consisted of a vacuum degasser, quaternary pump, automatic sampler and diode array detector (DAD). The DAD was connected with Waters ChemStation software. An Acquity UPLC H-class C18 column $(2.1 \times 50 \mathrm{~mm}$, inner diameter [ID] $1.7 \mu \mathrm{m}$ ) was used. Using acetonitrile and ultrapure water as eluents, the ginsenosides were separated by gradient elution. The flow rate was maintained at $0.3 \mathrm{~mL} \cdot \mathrm{min}^{-1}$. The injection volume was $3 \mu \mathrm{L}$, and the chromatogram was detected at $203 \mathrm{~nm}[25]$.

\subsubsection{Analysis of Monosaccharide}

Complete acid hydrolysis: First, $2 \mathrm{mg}$ of IRS was weighed, and then $0.5 \mathrm{~mL}$ of anhydrous methanol solution containing $2 \mathrm{~mol} / \mathrm{L} \mathrm{HCl}$ was added. The tube was sealed 
with $\mathrm{N}_{2}$ and the sample was hydrolyzed at $80^{\circ} \mathrm{C}$ for $16 \mathrm{~h}$ and then dried with air. Next, $0.5 \mathrm{~mL}$ of $2 \mathrm{~mol} / \mathrm{L}$ trifluoroacetic acid was added, and the sample was hydrolyzed for $1 \mathrm{~h}$ at $120^{\circ} \mathrm{C}$ and then transferred to an evaporating dish in a water bath at $45^{\circ} \mathrm{C}$. Absolute ethanol was added repeatedly to remove the trifluoroacetic acid, and then the sample was dried.

Derivatization of 1-phenyl-3-methyl-5-pyrazolone (PMP): First, $0.5 \mathrm{~mL}$ of PMP reagent and $0.3 \mathrm{~mol} / \mathrm{L} \mathrm{NaOH}$ solution were added to the monosaccharide sample after hydrolysis, and $0.3 \mathrm{~mL}$ of PMP was put into a $5 \mathrm{~mL}$ centrifuge tube after full dissolution and allowed to react for $30 \mathrm{~min}$ at $70{ }^{\circ} \mathrm{C}$ in a water bath. After centrifugation (5000 rpm, $5 \mathrm{~min}$ ), $0.3 \mathrm{~mL}$ of $0.3 \mathrm{~mol} / \mathrm{L} \mathrm{HCl}$ was added and mixed. Then, $2 \mathrm{~mL}$ of chloroform was added 3 times, the excess PMP reagent was extracted, the chloroform layer was removed by centrifugation (8000 rpm, $5 \mathrm{~min}$ ), the water layer was filtered with a $0.22 \mu \mathrm{m}$ (golden) filter and the samples were analyzed with high-performance liquid chromatography (HPLC).

HPLC analysis of monosaccharide-PMP derivatives: The mobile phase was $0.1 \mathrm{~mol} / \mathrm{L}$ PB buffer $(\mathrm{pH}=7.0)$ : acetonitrile at 82:18 $(v / v)$. The flow rate was $1.0 \mathrm{~mL} \cdot \mathrm{min}^{-1}$, the injection volume was $10 \mu \mathrm{L}$, and the detection wavelength was $245 \mathrm{~nm}$ [26].

\subsubsection{Analysis of Amino Acids}

Establishment of a standard curve: A mixed standard solution of amino acids was prepared, and the concentration of each component was $2.5 \mathrm{mmol} / \mathrm{L}$. The mixed standard solution was diluted with a $0.1 \mathrm{~mol} / \mathrm{L} \mathrm{HCl}$ solution, and the volume was fixed. An appropriate amount was placed into the sample bottle for testing. The VIS 1 wavelength was set to $570 \mathrm{~nm}$, and VIS 2 was set to $440 \mathrm{~nm}$.

Preparation of hydrolyzed amino acid samples: First, $100 \mathrm{mg}$ of IRS was accurately weighed into a $50 \mathrm{~mL}$ hydrolysis tube, $20 \mathrm{~mL}$ of $6 \mathrm{~mol} / \mathrm{L}$ hydrochloric acid solution was added and the tube was sealed with $\mathrm{N}_{2}$. The hydrolysis tube was hydrolyzed in a constanttemperature drying oven at $110^{\circ} \mathrm{C}$ for $22 \mathrm{~h}$. After cooling to room temperature, ultrapure water was used to fix the volume to $50 \mathrm{~mL}, 2 \mathrm{~mL}$ of the liquid was removed and the sample was evaporated to dryness in a vacuum drying oven at $70^{\circ} \mathrm{C}$. Then, the residue was rinsed with ultrapure water of the same volume and evaporated twice, and $2 \mathrm{~mL}$ of buffer $(0.02 \mathrm{~mol} / \mathrm{L} \mathrm{HCl})$ was added for dilution. The sample was shaken well and filtered with a $0.22 \mu \mathrm{m}$ (golden) filter into a sample bottle, where it was analyzed with an L-8900 amino acid automatic analyzer (Hitachi Company, Tokyo, Japan).

\subsubsection{Mineral Analysis}

$\mathrm{Al}, \mathrm{Ni}, \mathrm{Mn}, \mathrm{Cu}$ and $\mathrm{Zn}$ were determined by inductively coupled plasma mass spectrometry (ICP-MS) (Perkin Elmer Company, Waltham, Massachusetts, USA), and other elements were determined by flame atomic absorption spectrometry (FLAA) (Analytik Jena, Jena, Germany). The $0.5 \mathrm{~mL}$ liquid sample and $0.1 \mathrm{~g}$ solid sample were put into an acid mixture of $2.5 \mathrm{~mL}$ of $\mathrm{HClO}_{4}$ and $10 \mathrm{~mL}$ of $\mathrm{HNO}_{3}$ for digestion and then diluted with distilled water to $100 \mathrm{~mL}$.

\subsection{SEM and EDS Analyses}

The microstructure of the sediments was observed by scanning electron microscope (SEM) (FEI Company TM, XL-30 ESEM FEG, Hillsboro, OR, USA). The samples were sprayed with gold-palladium alloy (Cressington Scientific Instruments Ltd., Watford, UK). The scanning images were captured at accelerating voltages of $15 \mathrm{kV}$ and $20 \mathrm{kV}$ with magnifications of $500 \times$ and $1000 \times$ (scale of 20 and $50 \mu \mathrm{m}$ ).

X-MAX energy dispersive spectrometry (EDS) was used for qualitative and quantitative analysis of elements in the sediments (Oxford Instruments, UK).

\subsection{FT-IR and XRD Analysis}

Fourier transform infrared spectroscopy (FT-IR) analyses of IRS were performed using a VERTEX 70 FT-IR spectrometer (Bruker Optics Inc., Ettlingen, Germany). The sample 
was mixed with potassium bromide powder in a ratio of 1:100 $(w / w)$, and the spectra were obtained over the range of $4000-400 \mathrm{~cm}^{-1}$ with a resolution of $2 \mathrm{~cm}^{-1}$.

The structure of IRS was detected by X-ray diffractometry (D8 ADVANCE, Bruker AXS $\mathrm{GmbH}$ Co, Karlsruhe, Baden-Württemberg, Germany) equipped with theta-compensating

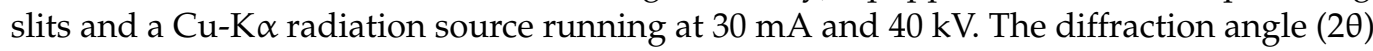
was adjusted from $5^{\circ}$ to $90^{\circ}$ at a rate of $2^{\circ} / \mathrm{min}$. The crystallinity index (CI, \%) of IRS was calculated by MDI Jade 6.0 software.

\subsection{Establishment of Chemical Composition Interaction Model}

Pectin $(20 \mathrm{mg} / \mathrm{mL})$, protein $(4 \mathrm{mg} / \mathrm{mL})$, proline $(0.25 \mathrm{mg} / \mathrm{mL})$, aspartic acid $(0.5 \mathrm{mg} / \mathrm{mL})$, glutamate $(0.5 \mathrm{mg} / \mathrm{mL})$, oxalic acid $(0.1 \mathrm{mg} / \mathrm{mL})$ and citric acid $(0.1 \mathrm{mg} / \mathrm{mL})$ were mixed with $\mathrm{Ca}^{2+}$ solution $\left(\mathrm{CaCl}_{2}, 50 \mathrm{mg} / \mathrm{L}\right)$ at $1: 1$ volume ratio, respectively. Pectin, dextran $(20 \mathrm{mg} / \mathrm{mL})$, oxalic acid and citric acid were mixed with protein at 1:1 volume ratio, respectively. The mixed solution was subjected to complexation simulation test at $4{ }^{\circ} \mathrm{C}$, $25^{\circ} \mathrm{C}$ and $80{ }^{\circ} \mathrm{C}$; the reaction time was $60 \mathrm{~min}$. Then, the turbidity was measured by WZB-172 turbidimeter (Shanghai INESA Scientific Instrument Co., Ltd., Shanghai, China).

\subsection{Data Analysis}

All the experiments were repeated three times, and the data were expressed as average values. SPSS statistical software was used to conduct one-way ANOVA and Duncan multiple-range tests to determine the significant differences between the mean and variables, and GraphPad Prism 6.0 was used to draw the chart.

\section{Results and Discussion}

\subsection{Observations of Sediment during Storage}

The sediments from ginseng extract stored at low temperature $\left(4^{\circ} \mathrm{C}\right)$ for $0-50$ days were analyzed. The amount of sediment increased during storage (Table 1). A small amount of sediment was visible to the naked eye starting on the second day. With an increase in storage days, the sediment in the ginseng extract continued to form and exhibited stratification. On the 10th day, most of the yellow sediment was produced, and white sediment began to form. From the 20th to the 30th day, the amount of yellow sediment increased continuously, while the amount of white sediment increased obviously. From the 30th to the 40th day, the amounts of both the yellow sediment and the white sediment increased slightly. From the 40th to the 50th day, the amounts of yellow sediment and white sediment did not increase. According to the sediment analysis (Figure 1), the total sediment showed an increasing trend from day 0 to day 50 , increased significantly in the first 30 days and tended to be stable on days 30-50. RS (67.5-73.5\%) was the principal part of the sediment, which played a dominant role in the change in total sediment. The proportion of IRS (26.5-32.5\%) was relatively small, and there was no significant change during storage. It was observed that most of the yellow sediment can be redissolved $\left(70{ }^{\circ} \mathrm{C}\right.$, $20 \mathrm{~min}$ ), while the white sediment is almost insoluble.

\subsection{Chemical Composition Analysis of the Extract and Sediments}

During low-temperature storage, the chemical components of the ginseng supernatant changed to different degrees (Table 2). With increased time, in addition to $\mathrm{Na}$, the elements $\mathrm{K}, \mathrm{Mg}, \mathrm{Ca}, \mathrm{Al}, \mathrm{Fe}, \mathrm{Mn}, \mathrm{Ni}, \mathrm{Sr}$ and $\mathrm{Ba}$ all showed a decreasing trend. There is no significant difference in $\mathrm{Mg}$ and $\mathrm{Mn}$. The highest content of $\mathrm{K}$ in the ginseng supernatant was $85-88 \%$ of the total metal elements. Most elements began to decline significantly on the 10th day. Contents of free amino acids, proteins, total sugar and total saponins did not change significantly during storage. The highest content in the supernatant was total sugar, which accounted for $71-74 \%$ of the main chemical components. Except Re, the content of ginsenosides changed significantly with the extension of storage time: the contents of $R g_{1}, R b_{1}, R c, R b_{2}, R b_{3}$ and $R d$ decreased significantly, and $R f$ showed an increasing trend. The total contents of the 8 ginsenosides also showed a significant downward trend. The 
results showed that sediment formation was the main reason for the decrease in chemical components in the supernatant.

Table 1. Observations of ginseng extract sediment formation during storage at $4{ }^{\circ} \mathrm{C}$.

\begin{tabular}{cccc}
\hline \multirow{2}{*}{ Storage (Days) } & Observation & Amount of Sediments & Description \\
\cline { 3 - 4 } & Yellow Sediments & White Sediments & The extract was clarified without sediment. \\
\hline 0 & No & No & Sittle \\
10 & Some & $\begin{array}{c}\text { Some quantity of yellow sediments and a } \\
\text { small quantity of white sediment appeared. }\end{array}$ \\
\hline
\end{tabular}

20

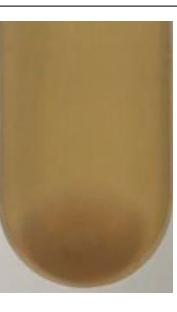

30

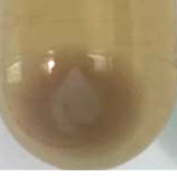

Much

Much

(1)

Much

Some
40

50

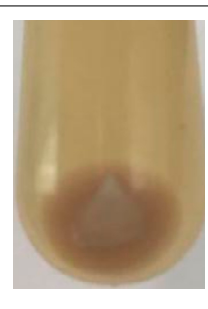

Little

Some

Some
Compared to the sediment stored for 10 days, the yellow sediment increased significantly, and the white sediment did not change significantly.

Compared to the sediment stored for 20 days, both the yellow sediment and the white sediment increased significantly.

Compared to the sediment stored for 30 days, both the yellow sediment and the white sediment increased but not significantly.

Compared to the sediment stored for 40 days, both the yellow sediment and the white sediment increased only slightly. 


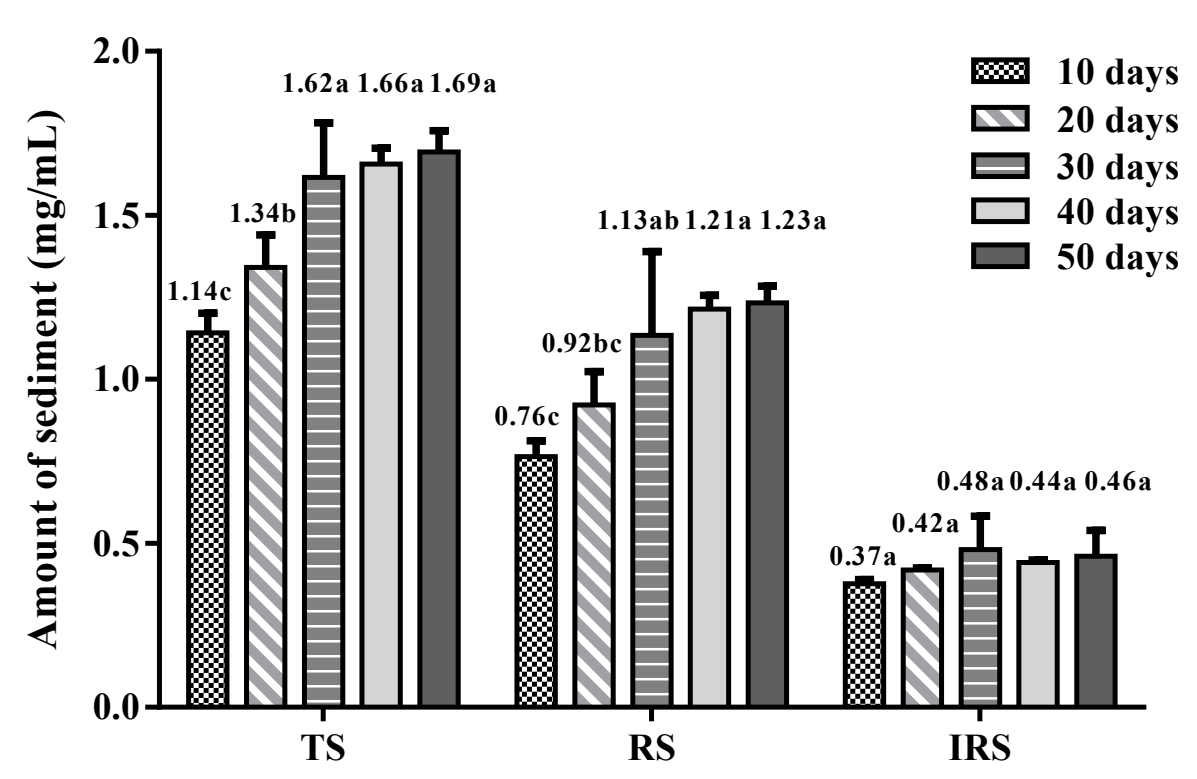

Figure 1. Total sediment (TS), reversible sediment (RS) and irreversible sediment (IRS) of ginseng extract during storage at $4{ }^{\circ} \mathrm{C}$. The data are means of three replicates. Different letters in the column groups indicate a significant difference $(p<0.05)$.

The data are the means of three replicates. Different letters on the same row in each group indicate significant differences between mean values $(p<0.05)$. Data $>10$ take integers, data between 1-10 keep 1 significant decimal place and data $<1$ keep 3 significant decimal places. Most of the RS in the ginseng extract was yellow sediment. Table 2 shows that there was no significant difference in the metal elements in RS during storage. Except for $\mathrm{K}$ and $\mathrm{Mg}$, other elements, such as $\mathrm{Na}, \mathrm{Ca}, \mathrm{Al}, \mathrm{Fe}, \mathrm{Mn}, \mathrm{Ni}$, $\mathrm{Sr}$ and $\mathrm{Ba}$, showed a downward trend. In addition, $\mathrm{K}$ was the element with the highest content in the RS, indicating that K participates to a higher degree in the RS. Free amino acids, protein and total saponins increased significantly with storage time, while total sugar content did not change significantly. According to the content, carbohydrates are the main component of $R S$, followed by proteins, total saponins and free amino acids. The contents of $\operatorname{Rg}_{1}, R e, R_{1}$, $\mathrm{Rc}, \mathrm{Rb}_{2}$ and total contents of ginsenosides increased significantly.

The key to removing the sediment from the ginseng extract is to inhibit the formation of IRS. We analyzed the metal elements in the IRS (Table 2). The elements increased significantly with the extension of storage time. $\mathrm{K}, \mathrm{Mg}, \mathrm{Na}, \mathrm{Ca}, \mathrm{Al}$ and $\mathrm{Fe}$ were the main elements in the IRS, and the content of Ca was the highest, accounting for $73-76 \%$ of the total metal elements, followed by K (9-16\%) and Al (5-8\%). During the 50 days of investigation, the contents of $\mathrm{K}, \mathrm{Al}$ and $\mathrm{Ni}$ increased more than 2 times, and the Ca content increased more than 4 times. This shows that a large number of metal elements participate in the formation of IRS. 
Table 2. Chemical composition analysis of ginseng supernatant, RS and IRS.

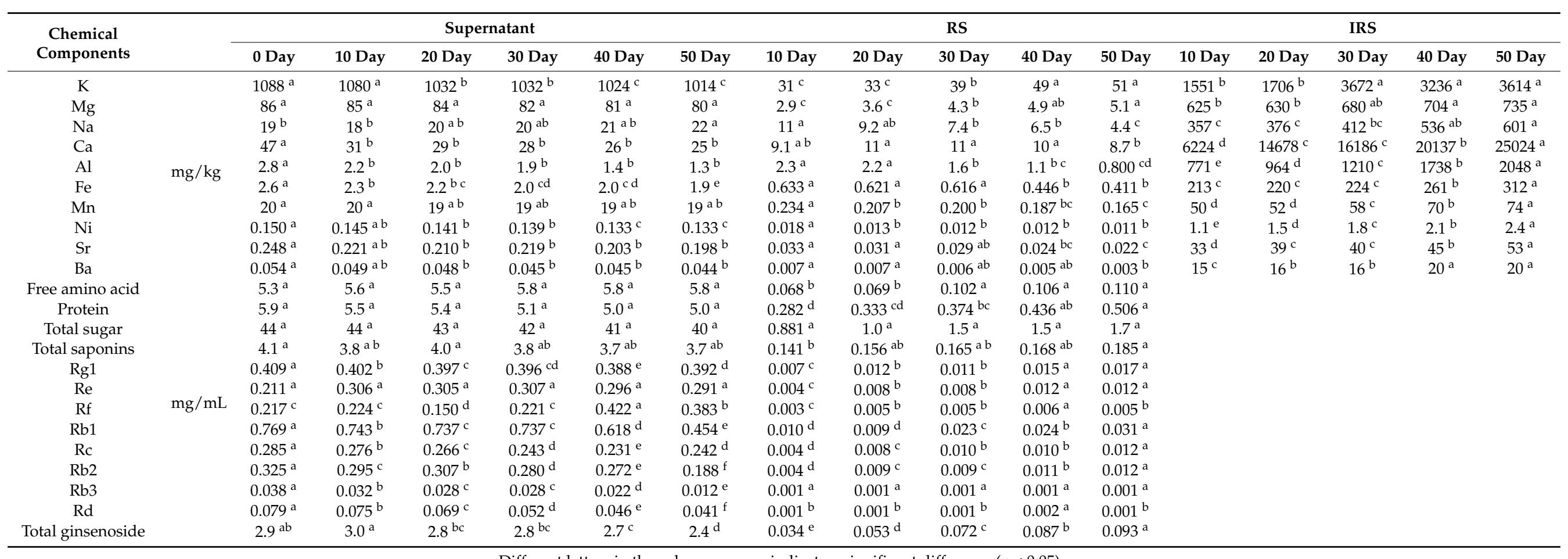

Different letters in the column groups indicate a significant difference $(p<0.05)$. 


\subsection{SEM and EDS Analysis}

In order to investigate the characteristics of white sediment (WS) and yellow sediment (YS), they were separated manually and scanned by electron microscopy (Figure 2). The results show that there are dense crystal structures in the white sediment (Figure 2a); The structure of yellow sediment is smooth without crystal structure (Figure $2 b$ ). It can be clearly seen that many encapsulated crystals (Figure 2c) are also present in the IRS. The IRS is composed of white sediment and yellow sediment. This crystal structure also exists in wine, which has been proved to be tartrate [16], and there is similar organic acid salt crystal in barberry juice [27], which is a common phenomenon in fruit juice or fruit wine. The above results indicated that the combination of metal ions and organic acids was involved in the formation of sediment during the storage process of ginseng extract, and most of the white sediment were metal salts. Through further energy spectrum analysis, the content of $\mathrm{Ca}$ in the WS was determined to be $8.72 \%$, which is significantly higher than that in the yellow sediment $(0.17 \%)$ and IRS $(5.32 \%)$. It can be inferred that the crystals in the white sediment are mainly $\mathrm{Ca}^{2+}$. In the yellow sediment, $\mathrm{C}$ and $\mathrm{O}$ accounted for $97.45 \%, \mathrm{~K}$ accounted for $1.6 \%$ and other elements accounted for a small amount. This result indicates that the main component of yellow sediment was carbohydrates, and some sylvite was formed.

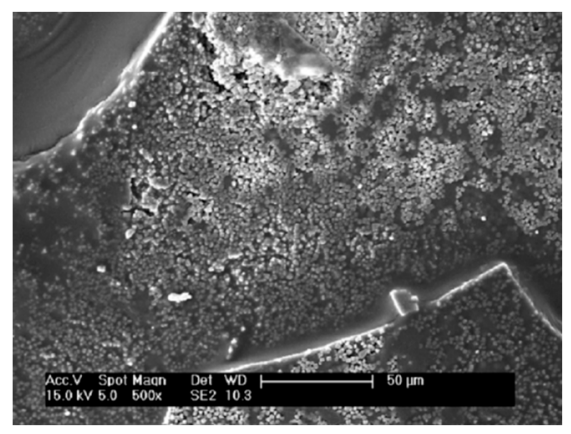

(a)

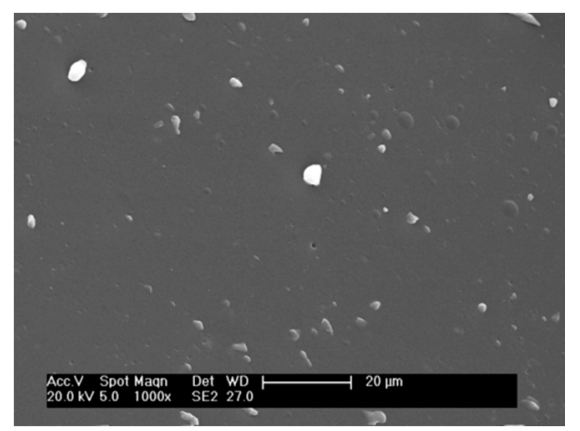

(b)

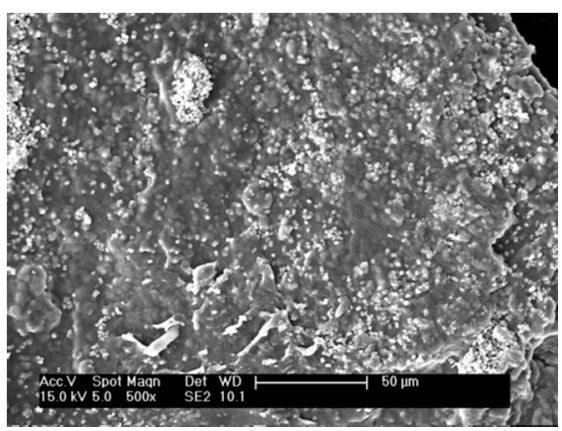

(c)

Figure 2. Scanning electron microscopy (SEM) images of white sediment (a), yellow sediment (b) and irreversible sediment (c).

\subsection{FT-IR and XRD Analyses}

The main functional groups in the IRS of ginseng water extract were determined by FTIR spectroscopy (Figure 3a). The FT-IR spectrum of IRS shows typical absorption peaks for some specific groups. The peak at $3315 \mathrm{~cm}^{-1}$ was attributed to the stretching vibration of O$\mathrm{H}$; the absorption peak here is wider, indicating that there are more hydrogen bonds in the association state [28]. The peak at $2929 \mathrm{~cm}^{-1}$ was attributed to the $\mathrm{C}-\mathrm{H}$ stretching vibration of carbohydrate methyl and methylene. The above absorption peaks are characteristic of polysaccharides [29]. The absorption bands between $1652 \mathrm{~cm}^{-1}$ and $1530 \mathrm{~cm}^{-1}$ were related to amide I ( $\mathrm{C}=\mathrm{O}$ stretching) and amide II bands ( $\mathrm{N}-\mathrm{H}$ stretching), respectively [30], which indicated the presence of uronic acid and protein in IRS. The peaks at $1323 \mathrm{~cm}^{-1}$ and $1245 \mathrm{~cm}^{-1}$ of IRS were attributed to the amide III band (C-N stretching). The secondary structure of the protein in IRS was determined to be an $\alpha$-helix structure by combining the amide I and III bands. The absorption peaks at $1148 \mathrm{~cm}^{-1}$ and $1027 \mathrm{~cm}^{-1}$, which are attributed to the stretching vibrations of $\mathrm{C}-\mathrm{O}-\mathrm{C}$ and $\mathrm{C}-\mathrm{O}-\mathrm{H}$ groups, indicate that pyran rings exist in IRS [31]. In addition, it was found that the IRS had a spectral peak very similar to that of the high-fat pectin-pea protein isolate complex [32]. In conclusion, the IRS had functional groups typical of polysaccharides and proteins, which might be caused by amidation between the amino groups of protein molecules and the carboxyl groups of pectin chains or by the production of insoluble components by protein molecules and polysaccharides produced under the action of static electricity. 


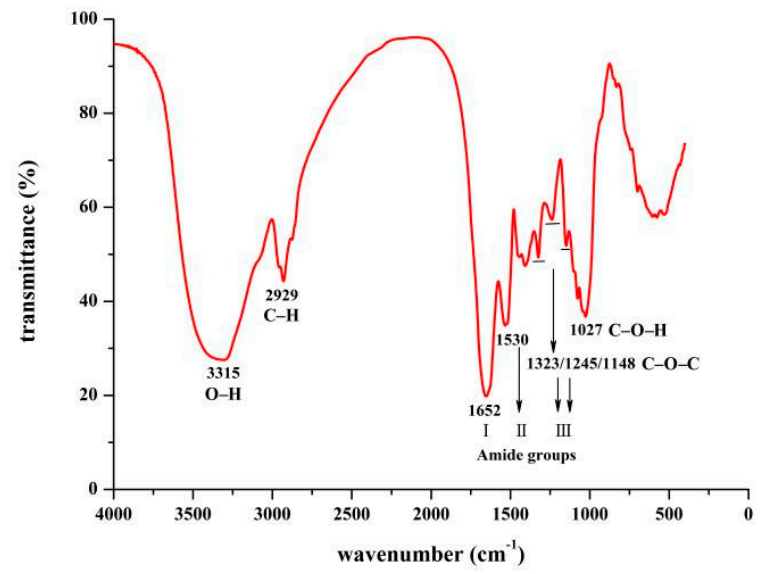

(a)

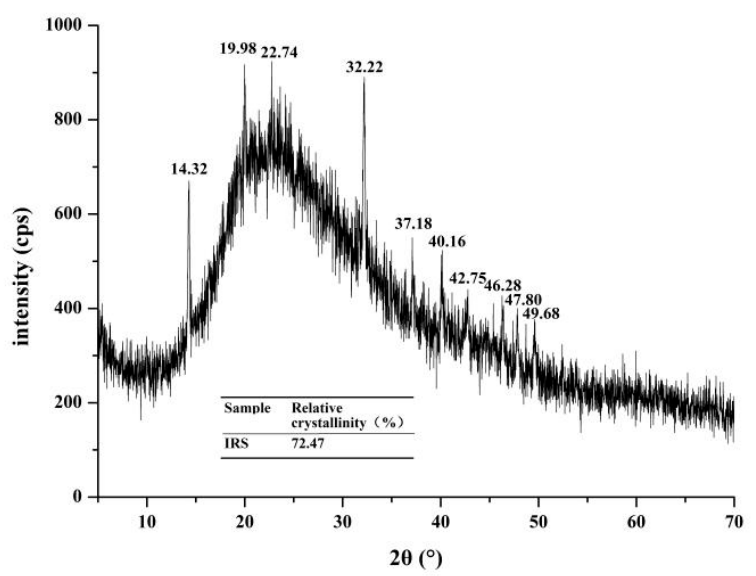

(b)

Figure 3. Fourier transform infrared spectroscopy (FT-IR, (a)) and X-ray diffractometry (XRD, (b)) results of IRS. The relative crystallinity was calculated by MDI Jade 6.0.

The crystal structure of IRS was analyzed by X-ray diffractometry. The XRD spectrum showed several obvious diffraction peaks (Figure 3a), which indicated that the IRS had a crystal structure consistent with the results observed by SEM (Figure 2c). The spectrum shows strong diffraction peaks at $2 \theta=14.32^{\circ}, 19.98^{\circ}, 22.74^{\circ}$ and $32.22^{\circ}$ and weaker diffraction peaks at $37.18-49.68^{\circ}$. It has a profile similar to that of the calcium oxalate dihydrate (COD) crystals obtained via electrocrystallization of indium oxide modified with R-chitosan fibers [33]. In addition, COD has been proved to be more regular than COM in crystal structure, showing a quadrilateral with blunt edges [27,34]. In Figure 2a, we observed similar structures, and some organic acids can also participate in sediment at low concentrations [19]. At the same time, the main diffraction peak was consistent with JCPDS card number 20-0233 (COD). The crystallinity of the IRS calculated by Jade 6.0 software was $72.47 \%$.

\subsection{Monosaccharide and Amino Acid Composition Analysis of IRS}

The IRS was hydrolyzed to detect 8 monosaccharide components. The results showed that the IRS contained 7 monosaccharides (Figure $4 b$ ), namely mannose (Man), rhamnose (Rha), D-gluconic acid (D-GluA), D-galacturonic acid (D-GalUA), glucose (Glu), galactose (Gal) and arabinose (Ara). Glucose was the main monosaccharide in the IRS, followed by D-galacturonic acid, and the remaining monosaccharides accounted for a small proportion. In addition, 17 amino acids were detected (Figure 4d). Proline was observed in channel 2, 
and the remaining amino acids were observed in channel 1 . The total amino acid content in the IRS was $479 \mathrm{mg} / \mathrm{g}$. The contents of aspartate (Asp, 11.98\%), glutamic acid (Glu, 11.92\%) and leucine (Leu, 9.60\%) were relatively high. The charge effect of polysaccharides and proteins was an important factor in inducing the transformation of polysaccharide-protein systems, and the polymerization of gel particles was positively correlated with the density of charge $[14,35]$. Protein and pectin easily bind together, and $\beta$-lactoglobulin can interact with at least 7 adjacent D-galacturonic acids, indicating that protein-pectin binding is closely related to the length of the pectin chain [36,37]. In addition, aspartate and glutamic acid in the IRS are acidic amino acids, and during the storage of the ginseng extract, these acidic amino acids can form insoluble amino acid salts with metal ions such as $\mathrm{Ca}[38,39]$. Leucine is a nonpolar amino acid with a hydrophobic side chain that has low solubility in water and easily precipitates. $\mathrm{Ca}^{2+}$ can combine with low-degree esterified pectin to form a stable egg-box structure $[40,41]$. This structure plays an important role in determining cell wall biomechanics and mediating cell adhesion and has a wide range of applications in the field of material engineering [42,43].

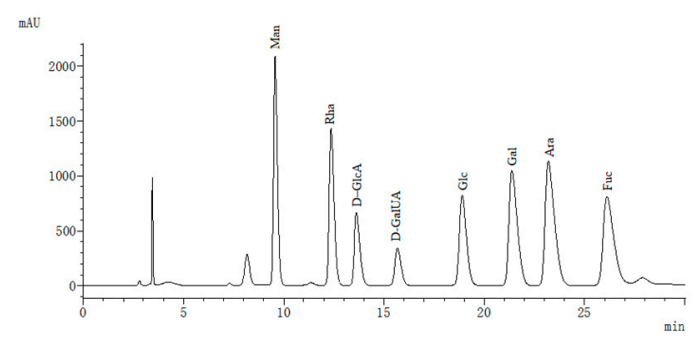

(a)

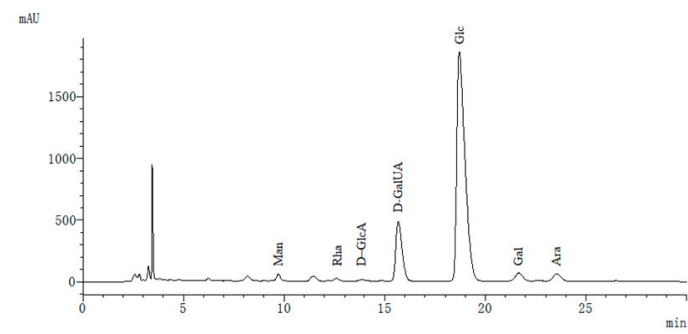

(b)

Figure 4. Cont. 


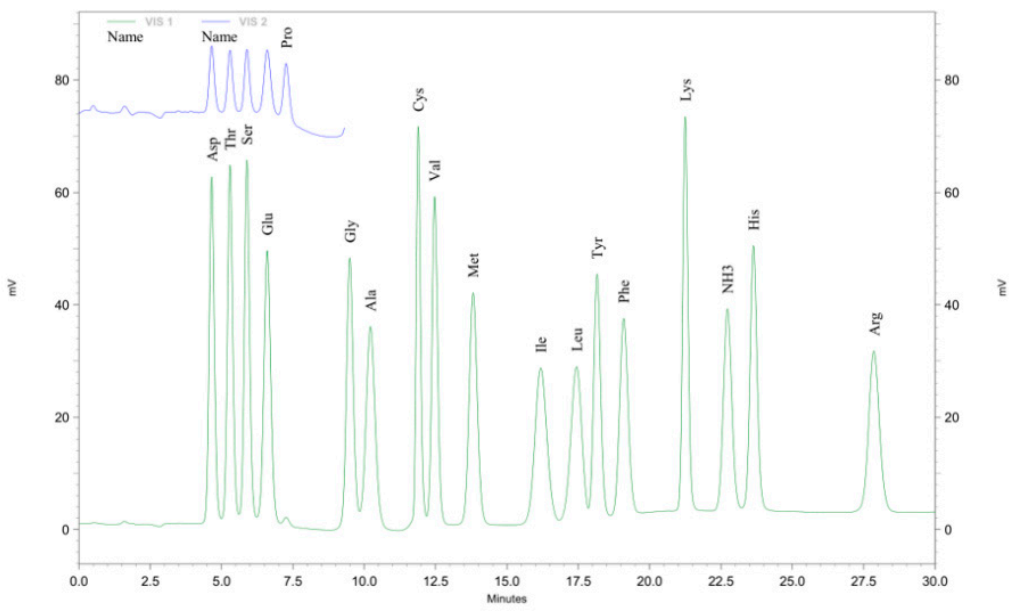

(c)

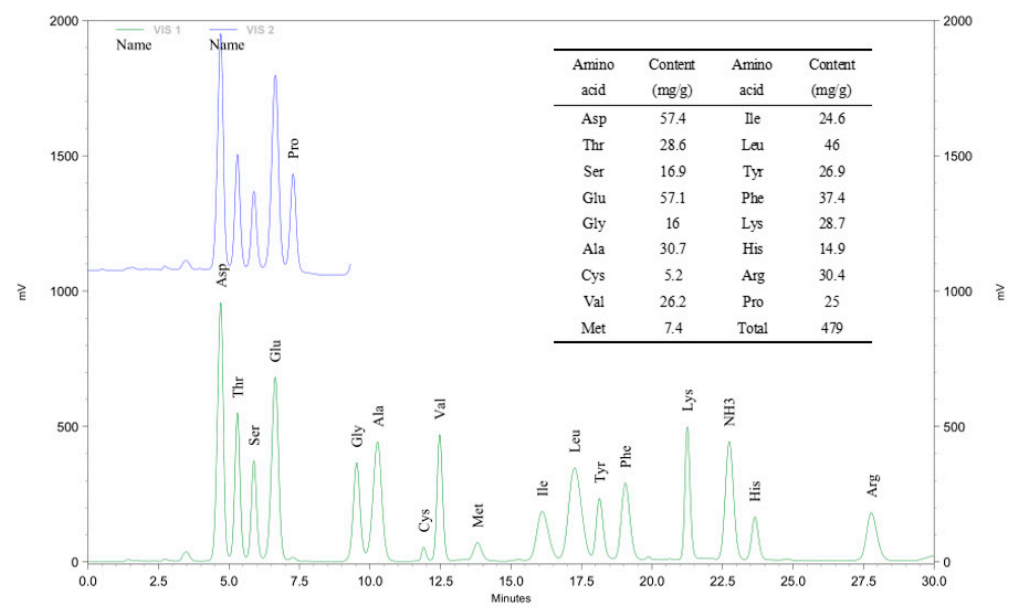

(d)

Figure 4. Composition of monosaccharides and amino acids in the IRS ((a): monosaccharide content, (b): monosaccharide composition in the IRS, (c): amino acid content, (d): amino acid composition in the IRS). Man: mannose; Rha: rhamnose; D-GlcA: D-gluconic acid; D-GalUA: D-galacturonic acid; Glc: glucose; Gal: galactose; Ara: arabinose; Fuc: fucose. Asp: aspartate; Thr: threonine; Ser: serine; Glu: glutamic; Gly: glycine; Ala: alanine; Cys: cysteine; Val: valine; Met: methionine; Ile: isoleucine; Leu: leucine; Tyr: tyrosine; Phe: phenylalanine; Lys: lysine; His: histidine; Arg: arginine; Pro: proline. Data are the means of three replicates.

\subsection{Verification of Chemical Composition Interaction}

The formation of complexes in solution is mainly affected by $\mathrm{pH}$, ionic strength, conformation, charge density, protein and polysaccharide concentration [39]. Based on the above results, the main chemical component interaction model system was established at $4{ }^{\circ} \mathrm{C}, 25^{\circ} \mathrm{C}$ and $80^{\circ} \mathrm{C}$, respectively, to observe the turbidity formation of the component interaction and determine the turbidity (Figure 5). The results showed that the turbidity of $\mathrm{Ca}^{2+}$ combined with pectin was significantly higher than when combined with other components, which verified that the complexation of $\mathrm{Ca}^{2+}$ with pectin was one of the reasons for the turbidity of the ginseng extract. The turbidity of $\mathrm{Ca}^{2+}$ and oxalic acid decreases with the increase of reaction temperature, which may be due to the decarboxylation reaction of oxalic acid during the heating process. In addition, under the three reaction conditions, the combination of protein and pectin is the most turbid and produces colloids. As we all know, the interaction between protein and polysaccharide is a common model of component interaction. It is widely used in the fields of food emulsifiers and bioactive substance deliv- 
ery and plays a crucial role in the structure and stability of food [44]. Under electrostatic action (with opposite charged groups), complex condensation or binding phase separation occurs, resulting in the formation of protein-polysaccharide complexes [45]. The pectin with higher local charge density has a stronger affinity for the binding site, so it is easier to complex aggregation with proteins, and high-charge polysaccharides are more conducive to the formation of precipitation [46]. The mixture of protein and oxalic acid at $25^{\circ} \mathrm{C}$ and $4{ }^{\circ} \mathrm{C}$ did not appear turbid, but the mixture appeared with flocculent precipitation at $80^{\circ} \mathrm{C}$. The high temperature caused protein denaturation, and then the secondary bonds were destroyed, hydrophobic bonds in the protein are exposed and precipitate.

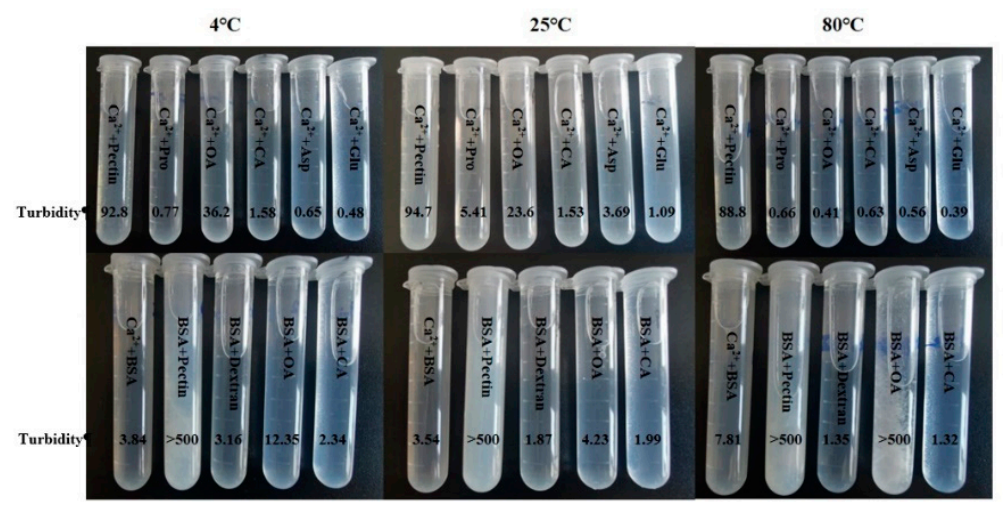

Figure 5. Turbidity of chemical composition interaction at different temperatures.

\section{Conclusions}

The purpose of this paper was to elucidate the formation mechanism of sediment in a ginseng extract during low-temperature storage. The sediment formation was clarified by observing the ginseng extract at low temperature for 50 days. The observations showed that the sediment was stratified, with yellow and white portions. The first 30 days of storage was the critical period for sediment formation, and after 30 days, the amount of sediment entered a stable period.

The chemical composition analysis of the extract and sediment showed that a large number of metal elements were involved in the formation of the sediment. The increase in $\mathrm{Ca}$ in the IRS was the most significant, which was more than 4 times. The SEM and EDS results also confirmed the existence of a large amount of $\mathrm{Ca}$, and the IRS was composed of white and yellow sediments. The FT-IR spectrum and X-ray diffraction results showed that there were protein and polysaccharide complex in the IRS, and the crystal structure was consistent with COD. Seven monosaccharides and 17 amino acids were detected in the IRS. Glucose and galacturonic acid were the main monosaccharides, and aspartate and glutamic acid were the main amino acids.

The interaction model of the key chemical components at the three reaction temperatures showed that the protein and pectin had a complex reaction due to electrostatic interaction, resulting in the greatest degree of turbidity and a colloidal structure. Secondly, $\mathrm{Ca}^{2+}$ and pectin form the egg-box structure will cause the liquid turbidity. The turbidity decreases after the high temperature reaction of $\mathrm{Ca}^{2+}$ and oxalic acid, it may be caused by the decarboxylation reaction of oxalic acid. Due to high temperature denaturation of protein, the turbidity of the mixture of protein and oxalic acid is much higher than that of normal and low temperature.

The above results indicated that the sediment of ginseng extract was formed by the physical factors and interaction of various chemical components. Regulation of IRS is the key to solve the sediment of ginseng extract. The stable state system can be improved by regulating $\mathrm{Ca}^{2+}$ complexation, changing protein and polysaccharide structures and increasing liquid viscosity. This study has practical significance for improving the quality and economic benefit of ginseng beverage. 
Author Contributions: Formal analysis, Writing-Original Draft, Visualization, Conceptualization and Funding acquisition, D.Q.; Writing-Review \& Editing, M.H.; Methodology, J.-B.C.; Investigation and Project administration, S.-S.L.; Supervision, L.-K.W.; Resources and Investigation, Y.-S.S. All authors have read and agreed to the published version of the manuscript.

Funding: This research received no external funding.

Institutional Review Board Statement: Not applicable.

Informed Consent Statement: Not applicable.

Conflicts of Interest: The authors have no interest conflict to declare.

\section{References}

1. Jeong, H.; Park, D.H.; Seo, H.G.; Choi, M.-J.; Cho, Y. Effect of Roasting Time and Cryogenic Milling on the Physicochemical Characteristics of Dried Ginseng Powder. Foods 2020, 9, 223. [CrossRef]

2. Yang, Y.; Yang, Y.; Qiu, H.; Ju, Z.; Shi, Y.; Wang, Z.; Yang, L. Localization of constituents for determining the age and parts of ginseng through ultraperfomance liquid chromatography quadrupole/time of flight-mass spectrometry combined with desorption electrospray ionization mass spectrometry imaging. J. Pharm. Biomed. Anal. 2021, 193, 113722. [CrossRef]

3. Hu, M.; Yang, J.; Qu, L.; Deng, X.; Duan, Z.; Fu, R.; Liang, L.; Fan, D. Ginsenoside Rk1 induces apoptosis and downregulates the expression of PD-L1 by targeting the NF-кB pathway in lung adenocarcinoma. Food Funct. 2020, 11, 456-471. [CrossRef]

4. Lu, G.; Liu, Z.; Wang, X.; Wang, C. Recent Advances in Panax ginseng C.A. Meyer as a Herb for Anti-Fatigue: An Effects and Mechanisms Review. Foods 2021, 10, 1030. [CrossRef]

5. Luo, Q.; Liu, J.; Wang, H.; Zhou, Y.; Liu, X.; Liu, Z. Structural characterization of ginseng oligopeptides and anti-aging potency evaluation in Caenorhabditis elegans. RSC Adv. 2020, 10, 39485-39494. [CrossRef]

6. Zhu, Z.; Xie, C.; Li, W.; Hang, F.; Li, K.; Shi, C.; Doherty, W.O. Nutritional and antioxidant properties of non-centrifugal cane sugar derived from membrane clarified juice. LWT 2020, 131, 109717. [CrossRef]

7. Shi, C.; Rackemann, D.W.; Moghaddam, L.; Wei, B.; Li, K.; Lu, H.; Xie, C.; Hang, F.; Doherty, W.O. Ceramic membrane filtration of factory sugarcane juice: Effect of pretreatment on permeate flux, juice quality and fouling. J. Food Eng. 2019, 243, 101-113. [CrossRef]

8. LaClair, C.E.; Etzel, M.R. Ingredients and pH are Key to Clear Beverages that Contain Whey Protein. J. Food Sci. 2010, 75, C21-C27. [CrossRef]

9. Malathy, R.; Prabakaran, M.; Kalaiselvi, K.; Chung, I.-M.; Kim, S.-H. Comparative Polyphenol Composition, Antioxidant and Anticorrosion Properties in Various Parts of Panax ginseng Extracted in Different Solvents. Appl. Sci. 2020, 11, 93. [CrossRef]

10. Xu, Y.-Q.; Chen, G.-S.; Wang, Q.-S.; Yuan, H.-B.; Feng, C.-H.; Yin, J.-F. Irreversible Sediment Formation in Green Tea Infusions. J. Food Sci. 2012, 77, C298-C302. [CrossRef]

11. Siebert, K.J. Haze formation in beverages. LWT 2006, 39, 987-994. [CrossRef]

12. Yang, W.; Deng, C.; Xu, L.; Jin, W.; Zeng, J.; Li, B.; Gao, Y. Protein-neutral polysaccharide nano- and micro-biopolymer complexes fabricated by lactoferrin and oat $\beta$-glucan: Structural characteristics and molecular interaction mechanisms. Food Res. Int. 2020, 132, 109111. [CrossRef]

13. Wu, D.; Lin, Q.; Singh, H.; Ye, A. Complexation between whey protein and octenyl succinic anhydride (OSA)-modified starch: Formation and characteristics of soluble complexes. Food Res. Int. 2020, 136, 109350. [CrossRef]

14. Schmitt, C.; Sanchez, C.; Desobry-Banon, S.; Hardy, J. Structure and Technofunctional Properties of Protein-Polysaccharide Complexes: A Review. Crit. Rev. Food Sci. Nutr. 1998, 38, 689-753. [CrossRef]

15. Akbulut, M.; Çalişir, S.; Marakoğlu, T.; Çoklar, H. Some physicomechanical and nutritional properties of barberry (Berberis vulgaris L.) fruits. J. Food Process. Eng. 2009, 32, 497-511. [CrossRef]

16. Kherici, S.; Benouali, D.; Benyetou, M.; Ghidossi, R.; Lacampagne, S.; Mietton-Peuchot, M. Study of Potassium Hydrogen Tartrate Unseeded Batch Crystallization for Tracking Optimum Cooling Mode. Orient. J. Chem. 2015, 31, 249-255. [CrossRef]

17. Mousavi, S.M.E.; Mousavi, M.; Kiani, H. Characterization and identification of sediment forming agents in barberry juice. Food Chem. 2020, 312, 126056. [CrossRef]

18. Xu, Y.-Q.; Zhong, X.-Y.; Yin, J.-F.; Yuan, H.-B.; Tang, P.; Du, Q.-Z. The impact of $\mathrm{Ca}^{2+}$ combination with organic acids on green tea infusions. Food Chem. 2013, 139, 944-948. [CrossRef]

19. Rodriguez-Clemente, R.; Correa-Gorospe, I.; De Castro, J. A new method for the stabilization of wines with respect to the potassium bitartrate precipitation. J. Enol. 1990, 41, 16-20. [CrossRef]

20. Zou, B.; Xu, Y.-J.; Wu, J.-J.; Yu, Y.-S.; Xiao, G.-S. Phenolic compounds participating in mulberry juice sediment formation during storage. J. Zhejiang Univ. Sci. B 2017, 18, 854-866. [CrossRef]

21. Yin, J.-F.; Xu, Y.-Q.; Yuan, H.-B.; Luo, L.-X.; Qian, X.-J. Cream formation and main chemical components of green tea infusions processed from different parts of new shoots. Food Chem. 2009, 114, 665-670. [CrossRef]

22. Nagalakshmi, S.; Ramaswamy, M.; Natarajan, C.; Seshadri, R. The rôle of added carbohydrates in tea 'cream' solubilisation. Food Chem. 1984, 13, 69-77. [CrossRef] 
23. Cuesta, G.; Suarez, N.; Bessio, M.I.; Ferreira, F.; Massaldi, H. Quantitative determination of pneumococcal capsular polysaccharide serotype 14 using a modification of phenol-sulfuric acid method. J. Microbiol. Methods 2003, 52, 69-73. [CrossRef]

24. Guo, Z.; Chen, L.; Zhao, C.; Huang, W.; Chen, Q. Nondestructive Estimation of Total Free Amino Acid in Green Tea by Near Infrared Spectroscopy and Artificial Neural Networks. In IFIP Advances in Information and Communication Technology; Springer: Berlin/Heidelberg, Germany, 2012; Volume 369, AICT (PART 2); pp. $43-53$.

25. Gao, K.; Chen, J.; Wang, Y.; Qi, Y.; Chen, L.; Li, S.; Sun, Y. Effects of 60Co- $\gamma$ and Electron Beam Irradiation on Storage Quality of Panax ginseng. Food Bioprocess Technol. 2018, 11, 1627-1638. [CrossRef]

26. Sun, M.; Wang, Y.; Li, W.; Cai, X.; Qi, D.; Zhang, Y.; Han, C. Comparison of the structures and prebiotic-like effects in vitro of polysaccharides from Coprinus comatus fruit body and mycelium. Int. J. Biol. Macromol. 2020, 165, 2621-2629. [CrossRef]

27. East, C.P.; Wallace, A.D.; Al-Hamzah, A.; Doherty, W.O.S.; Fellows, C.M. Effect of poly(acrylic acid) molecular mass and end-group functionality on calcium oxalate crystal morphology and growth. J. Appl. Polym. Sci. 2010, 115, 2127-2135. [CrossRef]

28. Wang, S.; Zhao, L.; Li, Q.; Liu, C.; Han, J.; Zhu, L.; Zhu, D.; He, Y.; Liu, H. Rheological properties and chain conformation of soy hull water-soluble polysaccharide fractions obtained by gradient alcohol precipitation. Food Hydrocoll. 2019, 91, 34-39. [CrossRef]

29. Naji-Tabasi, S.; Razavi, S.M.A.; Mohebbi, M.; Malaekeh-Nikouei, B. New studies on basil (Ocimum bacilicum L.) seed gum: Part I-Fractionation, physicochemical and surface activity characterization. Food Hydrocoll. 2016, 52, 350-358. [CrossRef]

30. Maftoonazad, N.; Shahamirian, M.; John, D.; Ramaswamy, H. Development and evaluation of antibacterial electrospun pea protein isolate-polyvinyl alcohol nanocomposite mats incorporated with cinnamaldehyde. Mater. Sci. Eng. C 2019, 94, 393-402. [CrossRef]

31. Li, S.-C.; Yang, X.-M.; Ma, H.-L.; Yan, J.-K.; Guo, D.-Z. Purification, characterization and antitumor activity of polysaccharides extracted from Phellinus igniarius mycelia. Carbohydr. Polym. 2015, 133, 24-30. [CrossRef]

32. Guo, Q.; Su, J.; Shu, X.; Yuan, F.; Mao, L.; Liu, J.; Gao, Y. Production and characterization of pea protein isolate-pectin complexes for delivery of curcumin: Effect of esterified degree of pectin. Food Hydrocoll. 2020, 105, 105777. [CrossRef]

33. Butto, N.; Vera, N.C.; Díaz-Soler, F.; Yazdani-Pedram, M.; Neira-Carrillo, A. Effect of Chitosan Electrospun Fiber Mesh as Template on the Crystallization of Calcium Oxalate. Crystals 2020, 10, 453. [CrossRef]

34. Liu, H.; Sun, X.-Y.; Wang, F.-X.; Ouyang, J.-M. Regulation on Calcium Oxalate Crystallization and Protection on HK-2 Cells of Tea Polysaccharides with Different Molecular Weights. Oxidative Med. Cell. Longev. 2020, 2020, 1-14. [CrossRef]

35. Warnakulasuriya, S.N.; Nickerson, M.T. Review on plant protein-polysaccharide complex coacervation, and the functionality and applicability of formed complexes. J. Sci. Food Agric. 2018, 98, 5559-5571. [CrossRef]

36. Mou.écoucou, J.; Villaume, C.; Sanchez, C.; Méjean, L. $\beta$-Lactoglobulin/polysaccharide interactions during in vitro gastric and pancreatic hydrolysis assessed in dialysis bags of different molecular weight cut-offs. Biochim. Biophys. Acta (BBA)-Gen. Subj. 2004, 1670, 105-112. [CrossRef]

37. Mravec, J.; Kračun, S.K.; Rydahl, M.G.; Westereng, B.; Pontiggia, D.; De Lorenzo, G.; Domozych, D.S.; Willats, W.G.T. An oligogalacturonide-derived molecular probe demonstrates the dynamics of calcium-mediated pectin complexation in cell walls of tip-growing structures. Plant J. 2017, 91, 534-546. [CrossRef]

38. Du, Q.; Ji, X.; Lyu, F.; Liu, J.; Ding, Y. Heat stability and rheology of high-calorie whey protein emulsion: Effects of calcium ions. Food Hydrocoll. 2021, 114, 106583. [CrossRef]

39. Van Dinh, Q.; Liu, J.; Dutta, P. Effect of Calcium ion on synaptotagmin-like protein during pre-fusion of vesicle for exocytosis in blood-brain barrier. Biochem. Biophys. Rep. 2020, 24, 100845. [CrossRef]

40. Li, L.; Fang, Y.; Vreeker, R.; Appelqvist, I.; Mendes, E. Reexamining the Egg-Box Model in Calcium-Alginate Gels with X-ray Diffraction. Biomacromolecules 2007, 8, 464-468. [CrossRef]

41. Nakauma, M.; Funami, T.; Fang, Y.; Nishinari, K.; Draget, K.I.; Phillips, G.O. Calcium binding and calcium-induced gelation of normal low-methoxyl pectin modified by low molecular-weight polyuronate fraction. Food Hydrocoll. 2017, 69, 318-328. [CrossRef]

42. Bouton, S.; Leboeuf, E.; Mouille, G.; Leydecker, M.-T.; Talbotec, J.; Granier, F.; Lahaye, M.; Höfte, H.; Truong, H.-N. QUASIMODO1 Encodes a Putative Membrane-Bound Glycosyltransferase Required for Normal Pectin Synthesis and Cell Adhesion in Arabidopsis. Plant Cell 2002, 14, 2577-2590. [CrossRef]

43. Domozych, D.S.; Sørensen, I.; Popper, Z.; Ochs, J.; Andreas, A.; Fangel, J.U.; Pielach, A.; Sacks, C.; Brechka, H.; Ruisi-Besares, P.; et al. Pectin Metabolism and Assembly in the Cell Wall of the Charophyte Green Alga Penium margaritaceum. Plant Physiol. 2014, 165, 105-118. [CrossRef] [PubMed]

44. Ye, A. Complexation between milk proteins and polysaccharides via electrostatic interaction: Principles and applications-A review. Int. J. Food Sci. Technol. 2008, 43, 406-415. [CrossRef]

45. Li, J.-E.; Wang, W.-J.; Zheng, G.-D.; Li, L.-Y. Physicochemical properties and antioxidant activities of polysaccharides from Gynura procumbens leaves by fractional precipitation. Int. J. Biol. Macromol. 2017, 95, 719-724. [CrossRef]

46. Sperber, B.L.; Schols, H.A.; Stuart, M.A.C.; Norde, W.; Voragen, A.G. Influence of the overall charge and local charge density of pectin on the complex formation between pectin and $\beta$-lactoglobulin. Food Hydrocoll. 2009, 23, 765-772. [CrossRef] 